\title{
Properties of fly ash geopolymer concrete designed by Taguchi method
}

\author{
Monita Olivia ${ }^{1}$, Hamid Nikraz \\ Department of Civil Engineering, Curtin University of Technology, GPO Box U1987, \\ Perth, WA 6845, Australia
}

\begin{abstract}
This paper presents an optimization of fly ash geopolymer mixtures by Taguchi method, and a study on the mechanical properties and durability of concrete produced from the optimal mixes. A total of nine mixtures were evaluated by considering the effects of aggregate content, alkaline solution to fly ash ratio, sodium silicate to sodium hydroxide ratio, and curing method. Ordinary Portland Cement (OPC) concrete of $55 \mathrm{MPa}$ strength was used as a control mix. Three optimal mixtures (T4, T7 and T10) were identified. Results show that the geopolymer concrete can be produced with of $55 \mathrm{MPa}$ at 28 days. They had higher tensile and flexural strength, produced less expansion and drying shrinkage, and showed moduli of elasticity that were $14.9-28.8 \%$ lower than those of the OPC control mix. The compressive strength of all geopolymer mixtures changed significantly at each wetting-drying cycle, but the weight losses were higher than that of the OPC concrete. Half-cell potential measurement showed that the geopolymer mixes were generally more prone to corrosion, although showed low-level corrosion activity and exhibited times to failure that were 3.86-5.70 times longer than those of the OPC concrete. The test results confirmed that the mechanical properties of the geopolymer mixtures tested are competitive with those of OPC concrete and provide a more durable alternative to the OPC concrete in a seawater environment.
\end{abstract}

Keywords: A. concrete; E. corrosion, mechanical

\footnotetext{
${ }^{1}$ Corresponding author email: monita.olivia@postgrad.curtin.edu.au, Tel: +61-89-2662652, Fax: +61-892662681, Present address: Civil Engineering Department, University of Riau, Pekanbaru, Indonesia, email: monita@unri.ac.id, Tel: +62-761-66596, Fax: +62-761-66595
} 


\section{Introduction}

Geopolymers, a new form of binder used in cement and concrete composites, are produced by the reaction of aluminosilicate material with alkaline solutions [1]. Instead of using metakaolin as the main binding material in concrete, slag and fly ash have become popular source materials for geopolymers because they have high silica and alumina contents and are abundantly available in landfill sites [2]. Fly ash is a heterogeneous material of variable chemical composition that can affect the final geopolymer product. Low calcium fly ash is preferred because high calcium poses the risk of fast setting. The main parameters affecting the fly ash geopolymer mixtures are the composition of the raw materials, the concentrations of alkaline solutions used, and the curing method. A combination of sodium silicate $\left(\mathrm{Na}_{2} \mathrm{SiO}_{3}\right)$ and sodium hydroxide $(\mathrm{NaOH})$ is most commonly used an alkaline activator [3], [4]; the ratio of these components is important in designing activators. Because of the slow reactivity of fly ash at ambient temperature, considerable heat must be applied to increase the kinetics energy and degree of the reaction that produces the geopolymer, thus increasing the density of the pore system and improving the mechanical properties of the resultant composite [5].

Various studies have highlighted the potential applications of fly ash geopolymer concrete because of its strength and durability in aggressive environments such as those containing sulphates or acids, or those subject to high temperatures [6], [7], and [8]. Fly ash geopolymers have greater durability than Ordinary Portland Cement (OPC) in such severe environments, which can be attributed to their lower calcium content. Calcium is a major component of OPC that reacts with the aggressive sulphates and acids. This research focused on the development of fly ash geopolymer mixtures for use in seawater environments. We used the Taguchi method to optimize the components of geopolymer concrete mixtures and investigated their mechanical properties and durability. 


\section{Experimental details}

\subsection{Materials}

Fly ash could be classified as class F by ASTM C618-08 [9] from Collie power station, Western Australia, and Ordinary Portland Cement Type I as specified in AS 2350.0 [10] were the main component of the concrete used in this study (Table 1). Coarse and fine aggregates in saturated surface dry conditions were used in this research. Crushed granite of three-grain sizes was used as coarse aggregate: $7 \mathrm{~mm}$ (2.58 specific gravity, $1.60 \%$ water absorption), $10 \mathrm{~mm}(2.62,0.74 \%)$, and $20 \mathrm{~mm}(2.65,0.58 \%)$. The fine aggregate used was uncrushed sand. All the aggregate was obtained from a quarry in Perth, Western Australia.

Combination of sodium hydroxide and sodium silicate were used as alkaline activators in this study. Sodium hydroxide in pearl form was dissolved in distilled water to produce a 14M sodium hydroxide solution. Grade D sodium silicate of specific gravity 1.52 and a modulus silicate ratio (Ms) of 2 (where $M s=\mathrm{SiO}_{2} / \mathrm{Na}_{2} \mathrm{O}, \mathrm{Na}_{2} \mathrm{O}=14.7 \%, \mathrm{SiO}_{2}=29.4 \%$ ) was used. $\mathrm{A}$ commercially available naphthalene sulphonate polymer-based superplasticizer was included in the mixture to improve workability.

\subsection{Determination of optimal mixtures}

The Taguchi method was used to determine optimal mixtures of the components of fly ash geopolymer concrete to maximize strength, while maintaining water absorption, sorptivity, and mass change during wetting-drying cycles and the risk of corrosion of steel reinforcement bars. The aim was to determine the optimal mix for application in a seawater environment. The behaviour of the various mixes was compared to that of 55 MPa strength OPC concrete.

Four factors related to strength and durability such as aggregate content, alkaline solution to fly ash ratio, sodium silicate to $\mathrm{NaOH}$ ratio and curing method were investigated (Table 2). 
The number of factors we considered and the values of those factors that we tested were chosen on the basis of previous research. Concrete usually consists of 75-80\% aggregates; so concrete containing 75, 77, and 79 wt \% aggregate was considered. An alkaline solution/fly ash ratio within the range of $0.30-0.40$ has been shown to improve strength and microstructure of the geopolymer concrete [11]. Sodium silicate to sodium hydroxide ratios of 1.5-2.5 (maximum of 2.5 for economic reasons) have been shown to be appropriate [3]. Three curing methods were used: curing at $60^{\circ} \mathrm{C}$ for 24 hours, at $70^{\circ} \mathrm{C}$ for 12 hours and at $75^{\mathrm{O}} \mathrm{C}$ for 24 hours [3], [12], and [13].

We used one of the orthogonal arrays, i.e. $\mathrm{OA}_{9}\left(3^{4}\right)$ developed by Taguchi to represent a full factorial experiment (Table 3) [14]. The component variables for each of the mixtures (T1-T9) are given in Table 4. Table 5 shows the proportions used for the geopolymer concrete with the $\mathrm{H}_{2} \mathrm{O} / \mathrm{Na}_{2} \mathrm{O}$ ratio kept constant at 12.50 to obtain workable mixes [11]. The proportions were determined by a basic calculation to design fly ash geopolymer concrete developed at Curtin University [15].

The trial mix results were evaluated for compressive strength by calculating a response index for each factor based on signal-to-noise ratio $(\mathrm{S} / \mathrm{N})$ principles [14]. That is, a higher $\mathrm{S} / \mathrm{N}$ provides a 'better' response index. Note that our response index calculations for the original nine mixes indicated that an additional mix (T10, not included in the Taguchi array we used) was worthy of consideration, and we included this additional mix in our subsequent analyses.

\subsection{Preparation, casting and curing of test specimens}

Geopolymer concrete samples were prepared by mixing dry materials (fly ash, fine and coarse aggregates) and alkaline activators (sodium silicate, sodium hydroxide, water and superplasticizer) in a 70-L pan mixer. The dry materials were mixed first and the alkaline 
activators were then poured into the pan and mixed continuously for approximately 4 min until the mixture was glossy and well combined.

The specimens were cast in cylinders of $100 \mathrm{~mm}$ diameter and $200 \mathrm{~mm}$ length (100 x 200 $\mathrm{mm}$ ) for measurement of compressive strength, Young's modulus of elasticity and weight change; 150 x 300 mm cylinders were used for splitting tensile strength tests, 100 x $50 \mathrm{~mm}$ cylinders for water absorption, and cylinders 100 x $110 \mathrm{~mm}$ for sorptivity tests. Blocks with dimensions of $100 \times 100 \times 400$ mm were used to measure flexural strength, and $25 \times 25 \times 250$ mm blocks for shrinkage. “Lollipop” specimens, 100 x $200 \mathrm{~mm}$ concrete cylinders with central 16 mm diameter steel bars, were used for half-cell potential and accelerated corrosion tests. Three specimens were produced for each test and the results are provided as averages.

The geopolymer concrete specimens were steam cured under three different curing regimes (Table 4). The inside surfaces of the moulds were coated with a water-based released agent to prevent the samples from sticking to the moulds surface during the steam curing process. After removal from their molds, the specimens were air cured in a curing room at 23$25^{\mathrm{O}} \mathrm{C}$. The OPC concrete control specimens were removed from their molds after 24 hours of air curing and placed in the water ponds for 28 days. They were removed from the ponds and air dried in the curing room until testing commenced.

\subsection{Testing of specimens}

Slump tests were carried out in accordance with the Australian Standard AS 1012.3.1 [16]. The $\mathrm{pH}$ of each fresh concrete specimen was determined using a method developed by Grubb, et al. [17]. The standards applied for strength tests were: AS 1012.9 for compressive strength [18], AS 1012.10 for Brazilian splitting tensile strength [19], AS 1012.11 for flexural strength [20], and AS 1012.17 for Young's modulus of elasticity [21]. Drying shrinkage was determined according to AS 1012.13 [22], and water absorption and Apparent Volume of 
Permeable Voids (AVPV) according to ASTM C642-06 [23]. Sorptivity testing was conducted according to a method developed by GHD Pty Ltd [24].

Resistance to accelerated wetting-drying cycles in 3.5\% $\mathrm{NaCl}$ was determined for mixes T4 and OPC using the method of Kasai and Nakamura [25]. For these tests, specimens were subjected to immersion in $3.5 \% \mathrm{NaCl}$ for 24 hours followed by drying in an oven at $80^{\circ} \mathrm{C}$ for 24 hours. Changes of compressive strength and weight were determined after 10 cycles for the trial mixes, and at 14, 45 and 100 cycles for the control and optimal mixtures.

To investigate the resistance to corrosion of steel within the geopolymer concrete, half-cell potential measurement according to ASTM C876-09 [26] and accelerated corrosion tests using the impressed voltage method [27] were carried out on the lollipop specimens. The half-cell potential was measured using a $\mathrm{Ag} / \mathrm{AgCl}$ reference electrode while the lollipop samples were immersed in a $3.5 \% \mathrm{NaCl}$ solution. Triplicate readings were taken for each sample and the values reported here are average of the results obtained for three specimens (i.e. averages of nine values). A constant voltage (30V) was used for the accelerated corrosion tests, for which the electrolyte was $3.5 \% \mathrm{NaCl}$ solution.

\section{Results and Discussion}

\subsection{Optimization of key components of fly ash geopolymer concrete}

Compressive strength, weight loss during drying cycles and total weight change after completion of wetting-drying cycles, sorptivity and AVPV were used as evaluation criteria for the trial mixes.

Compressive strength increased with concrete age, except for mixes T3 and T7 (Table 6). The compressive strength of geopolymer is known to vary up to 28 days after curing because continuation of the geopolymerisation process after curing; these variations are dependent also on mixture proportions [28]. Mix T7 gave the highest compressive strength at 28 days 
(54.89 MPa) and mix T9 gave the lowest (29.71 MPa) at 28 days. The high compressive strength of mix T7 may reflect the high aggregate content of this mix.

Table 7 shows the values of various evaluation criteria after completion of wetting-drying cycles. All mixes showed high compressive strength after 10 wetting-drying cycles in salt water. Changes of compressive strength after the completion of wetting-drying cycles were in the range 19.22-42.85\% and weight loss after final drying was in the range $1.97-3.14 \%$, which is low for concrete in an aggressive environment. Our results show that the sorptivity and strength of geopolymer are inversely related. For high strength mixes, sorptivity tends to be low, despite the high AVPV of those mixes.

The response index for each factor was calculated by summing the strengths at ages of 1 , 7, 28 days for each trial mix that contained that factor dividing by the sum by the number of measurements (i.e. taking the average). For example, factor A1 was tested in trial mixes T1, T2, and T3 (Table 6). The response index for factor A1 on day 1 after curing was, therefore, the average of the compressive strengths for trials T1 to T3 for day 1 (Figure 1). Factor A1 gave a greater response index (compressive strength) than factors A2 and A3 on days 1, 7, 28, and is therefore the optimal value for factor A. Optimal values were calculated in the same way for factors B, C, and D.

There were increases of strength over the 28-day period after curing for aggregate contents of 1800,1848 , and $1896 \mathrm{~kg} / \mathrm{m}^{3}$ (Figure 1). Of these, the mixture containing $1800 \mathrm{~kg} / \mathrm{m}^{3}$ aggregate (A1) developed the greatest strength. High alkaline solutions contents (B2 and B3) also provided strength increases over the 28 days, but maximum strength was achieved with a lower contents of alkaline solution (B1), and this was achieved earlier than for high alkaline content mixes (B2 and B3). Higher amounts of sodium silicate (C3) had a considerable positive effect on strength development, especially in the early stages after curing. One day after curing, and thereafter, there was a little difference in the strength developed for mixtures 
with sodium silicate/NaOH ratios of 1.5 (C1) and 2.0 (C2). High temperature and duration of curing (D3) increased the strength substantially compared to curing at lower temperatures (D1, D2).

The results of our calculations of response indices for the four factors suggested that a mix not yet tested was worthy of consideration: that is, mix A1B1C3D3 (aggregate content 1800 $\mathrm{kg} / \mathrm{m}^{3}$, alkaline solution/fly ash ratio 0.3 , sodium silicate/ $\mathrm{NaOH}$ ratio 2.5 and 24 hours curing at $\left.75{ }^{0} \mathrm{C}\right)$. We named this mix T10.

The effects of changing each component of the mixture while maintaining constant proportions of other components are shown in Table 8. Analysing these data in the same way as above, the optimal mixtures were: mix T7 (A3B1C3D2) for low mass loss, mix T10 (A1B1C3D3) for low sorptivity, and mix T7 for low AVPV (A2B1C2D3) showed only moderate strength, but better workability and potentially has better durability than mix T7.

On the basis of the above analyses, we chose a subset set of three mixtures (T4, T7, T10) for further evaluation (Table 9).

\subsection{Fresh and mechanical properties of the three optimal mixtures}

Although the slump values for the fresh geopolymer mixes were at least twice that of the OPC concrete (Table 10), their workability was considerably lower. The fresh geopolymer mixes were stiff and tacky because of their low water content and the presence of highly soluble silicate [29]. The $\mathrm{pH}$ values of the fresh geopolymer concretes were higher than hat of the OPC concrete because of their high alkaline contents (Table 10). A high pH is required to start the geopolymerisation process during heat curing.

Each of the three optimal geopolymer mixtures produced concrete of greater than $55 \mathrm{MPa}$ strength 28 days after curing (Table 10). There was a gradual increase in strength up to 91 days for each of the geopolymer mixes and for the OPC concrete. For the geopolymer mixes 
this gradual increase has been attributed to a slow reaction to refill the gel structure and develop a crystalline structure [29]. At 28 days, mixes T7 and T4 had developed similar strength to the control mixture. Compared to the OPC concrete, mix T10 showed higher strength at 7 and 28 days, but lower strength at 91 days. The small increase in strength of mix T7 between 28 and 91 days probably reflects the high aggregate content in this mixture.

Both splitting tensile strength and flexural strength of the geopolymer concretes increased with increasing concrete age (Table 11). The tensile strength of mix T10 was 8-12\% higher than that of the OPC concrete at 28 and 91 days, which may reflect effective bonding between the geopolymer matrix and aggregate [30]. The flexural strength of the geopolymer concretes was 1-1.4 times higher than that of the OPC concrete at 28 and 91 days. It appears that the development of the tensile strength of the geopolymer concretes was a result of the same process that produced their compressive strength. The high tensile and flexural strength of the geopolymer concretes help to decrease the rate and extent of cracking in response to corrosion of steel reinforcements [31].

The modulus of elasticity of geopolymer concrete was 14.9-28.8\% lower than that of the OPC concrete, which is supported by previous research [28] and indicates that high silicate content might increase the elasticity of geopolymer concrete. The low modulus of elasticity decreases the rate of crack propagation caused by corrosion of steel reinforcements, as is the case for high tensile and compressive strength [31].

Drying shrinkage of the control mix over the 11 weeks after curing was more than 400 microstrain units, and then decreased to around 300 microstrain units (Figure 2). Drying shrinkage was also evident in mix T10, which followed a trend similar to that reported by Wallah [32]. The shrinkage of mix T10 (about 100 microstrain units) was less than that of the OPC concrete and slowed after 28 days. Mixes T4 and T7 showed minor expansion throughout the 91 days after curing although there was less expansion of mix T7 than of mix 
T4. There was no water loss from the geopolymer concretes either during geopolymerisation or after steam curing, which we attribute to the low water content of the geopolymer mixtures.

\subsection{Water absorption, AVPV, effective porosity and sorptivity}

The fly ash geopolymer concrete mixes had lower water absorption, AVPV, and effective porosity than the OPC concrete at 28 and 91 days (Table 13). Although the geopolymer concretes were prepared with different mixtures of components, similar values of water absorption $(<5 \%)$ and AVPV $(<12 \%)$ were obtained. There was an overall decrease in effective porosity for all mixes after 28 days, indicative of a reduction of porosity. For all mixes except T10, sorptivity showed a general increase after 28 days (Table 14), indicating development of capillary porosity network.

\subsection{Concrete degradation during wetting-drying cycles}

Concrete degradation in wetting-drying was measured by the weight losses during individual drying cycles (Figure 3), total changes of weight over the full sequence of wetting drying cycles (Figure 4), and changes of compressive strength (Table 15). In this research, only mix T4 was used, since it has equivalent strength with control mix and better workability than the other geopolymer mixes. Weight losses during drying of mix T4 at cycles 45 and 100 were $1.27 \%$ and $1.48 \%$, respectively, and were greater than the corresponding weight losses of the control mix (Figure 3). Sudden increase of weight loss during the first ten or so cycles for both mix T4 and the control mix indicate that, for these early cycles, evaporation during drying was greater than water absorption. The total weight of mix T4 had declined by $0.83 \%$ after 80 cycles, providing evidence of concrete cover degradation (Figure 4). The opposite trend was observed for the control mix, which showed a gradual increase in total weight that 
reached $0.41 \%$ at 80 cycles, which might reflect an increase of concrete density after the wetting-drying cycles.

The concrete cover of mix T4 appeared to show less resistance to wetting-drying than the OPC concrete; however, mix T4 showed increases of compressive strength of $21.41 \%$, 24.77\% and $12.96 \%$ at 14,45 , and 100 cycles, respectively (Table 15). Repeated drying at temperatures of $80^{\circ} \mathrm{C}$ for up to 100 cycles might have caused structural and phase composition change that increased the mechanical strength of the fly ash geopolymer material. However, between cycles 45 and 100, the strength of mix T4 decreased by $11.81 \%$. Visual examination of the T4 samples after 100 cycles showed that the concrete had lost integrity, there was considerable loss of fine aggregate and shallow holes were distributed on the surface of the concrete.

\subsection{Corrosion performance of concrete}

Each of the three mixes tested for corrosion demonstrated half-cell potentials lower (higher negative values) than $-404 \mathrm{mV}$ (using a $\mathrm{Ag} / \mathrm{AgCl}$ reference electrode) at 91 days (Figure 5). According to ASTM C876, concrete of corrosion potential lower than $-404 \mathrm{mV}$ is prone to severe corrosion [33]. It is likely that penetration of chloride ions from the $\mathrm{NaCl}$ solution into the concrete caused these low values. After about 20 days, the corrosion potential of the control concrete was relatively stable at about $-250 \mathrm{mV}$, indicating that steel reinforcements in it would not be subject to active corrosion. The highly negative potential readings indicating high risk of corrosion for the geopolymer concretes might be explained by the lower $\mathrm{pH}$ of the aqueous solutions during the half-cell potential measurement (Figure 6).

Accelerated corrosion tests (Figure 7) showed that the geopolymer concretes exhibited considerably lower corrosion activity $(<100 \mathrm{~mA})$ at 20 days than did the control concrete. Previous researchers who compared corrosion activity for concretes coated with fly ash and 
metakaolin geopolymer with those without geopolymer coating demonstrated similar results to ours $[34,35]$.

Time to failure ( $\left.\mathrm{t}_{\text {fail }}\right)$ was defined as the onset time of current increase [36]. Time to failure for the three geopolymer concrete mixes was 3.86-5.70 times longer than that of the concrete (Table 16). Under the impressed voltage, a crack appeared suddenly in the concrete when $t_{\text {fail }}$ was reached, and this was followed immediately by high current readings. The large amounts of fly ash and alkaline activators in the geopolymer concrete mixes increase the availability of ions that can produce high electrical resistance at high impressed voltage. This enhances the cathodic reaction and reduces the rate of corrosion, which in turn reduces the tensile stress of the specimens, thus decreasing the risk of cracking and clearly extending the time to failure.

\section{Conclusions}

The optimal fly ash geopolymer concrete for use in a seawater environment has high compressive, tensile and flexural strength, and low modulus of elasticity, drying shrinkage, water absorption, and sorptivity. We produced geopolymer concrete with strength equivalent to $55 \mathrm{MPa}$ at 28 days. The trial mixes of fly ash geopolymer concrete showed tensile strengths as much as $8-12 \%$ greater than that of OPC concrete. The flexural strengths of the geopolymer concretes we tested up to 1.4 times higher than those of OPC concrete, and their moduli of elasticity were $14.9-28.8 \%$ lower. The geopolymer concretes also exhibited less expansion and drying shrinkage than the OPC concrete. Water absorption of the geopolymer concretes was lower than that of OPC concrete, but their sorptivity increased after 28 days after curing. When the geopolymer concretes were subjected to repetitive cycles of wetting in salt water and drying at high temperatures, they exhibited significant weight loss and degradation of concrete cover, but the wetting-drying cycles increased the compressive strength compared to that of OPC concrete. Although half-cell potential tests showed that the 
geopolymer concretes were more prone to corrosion than the OPC concrete, their time to failure under impressed voltage accelerated corrosion tests were 3.86-5.70 times longer than that of OPC concrete.

The test results showed that the mechanical properties of the geopolymer concrete mixtures were tested are competitive with those of OPC concrete and can provide a more durable alternative to OPC concrete in a seawater environment.

\section{Acknowledgements}

We acknowledge support provided by the Australian Development PhD Scholarship to M. Olivia, and thank Ashley Hughes, Gunawan Wibisono and Jim Sherlock for the laboratory work and instruments setup.

\section{References}

[1] Davidovits J. Geopolymer: inorganic polymer new materials. J Therm Anal. 1991;37:1633-56.

[2] ADAA Statistics Page [Internet]. Ash Development Association of Australia. 2008 [updated 2009 October 15; cited 20 May 2010]. Available from: http://www.adaa.asn.au/statistics.htm

[3] Hardjito D, Wallah SE, Sumajouw DMJ, Rangan BV. On the development of fly ashbased geopolymer concrete. ACI Mat J. 2004;101:467-72.

[4] Wongpa J, Kiattikomoi K, Jaturapitakkul C, Chindaprasirt P. Compressive strength, modulus of elasticity, and water permeability of inorganic polymer concrete. Mater Des. 2010; 31: 4748-54.

[5] Kovalchuk G, Fernandez-Jimenez A, Palomo A. Alkali-activated fly ash: Effect of thermal curing conditions on mechanical and microstructural development- Part II. Fuel. 2007;86:315-22.

[6] Bakharev T. Durability of geopolymer materials in sodium and magnesium sulfate solutions. Cem Concr Res. 2005;35:1233-46.

[7] Song XJ, Marosszeky M, Brungs M, Munn R. Durability of fly ash based geopolymer concrete against sulphuric acid attack. In: Proceedings of 10DBMC International Conference on Durability of Building Materials and Components, Lyon; 2005. Paper number TT3-48.

[8] Kong DLY, Sanjayan JG, Sagoe-Crentsil K. Comparative performance of geopolymers made with metakaolin and fly ash after exposure to elevated temperatures. Cem Concr Res. 2007;37:1583-9.

[9] ASTM C618-08. Standard specification for coal fly ash and raw or calcined natural pozzolan for use in concrete. Philadelphia: ASTM International; 2008. 
[10] AS 2350.0. Methods of testing portland and blended cements. Sydney: Standards Australia Limited; 1999.

[11] Palomo A, Grutzeck MW, Blanco MT. Alkali-activated fly ashes: A cement for the future. Cem Concr Res. 1999;29:1323-9.

[12] van Jaarsveld JGS, van Deventer JSJ, Lukey GC. The effect of composition and temperature on the properties of fly ash- and kaolinite-based geopolymers. Chem Eng J. 2002;89:63-73.

[13] Shindunata, van Deventer JSJ, Lukey GC, Xu H. Effect of curing temperature and silicate concentration on fly ash based geopolymerization. Ind Eng Chem Res. 2006;45:3559-68.

[14] Ross PJ. Taguchi techniques for quality engineering. New York: McGraw-Hill; 1988.

[15] Rangan BV. Low calcium fly ash based geopolymer concrete. In: Nawy EG, editor. Concrete Construction Engineering Handbook. 2nd ed: Taylor \& Francis; 2008.

[16] AS 1012.3.1. Methods of testing concrete- Determination of properties related to the consistency of concrete- Slump test. Sydney: Standards Australia Limited; 1998.

[17] Grubb JA, Limaye HS, Kakade AM. Testing pH of concrete. Concrete International. 2007:78-83.

[18] AS 1012.9. Methods of testing concrete- Determination of compressive strength of concrete specimens. Sydney: Standards Australia Limited; 1999.

[19] AS 1012.10. Methods of testing concrete- Determination of indirect tensile strength of concrete cyclinders (Brasil or splitting test). Sydney: Standards Australia Limited 2000.

[20] AS 1012.11. Method of testing concrete- Determination of the modulus of rupture. Sydney: Standards Australia Limited; 1985.

[21] AS 1012.17. Methods of testing concrete- Determination of the static chord modulus of elasticity and Poisson's Ratio of concrete specimens. Sydney: Standards Australia Limited; 1997

[22] AS 1012.13. Methods of testing concrete- Determination of the drying shrinkage of concrete for samples prepared in the field or in the laboratory. Sydney: Standards Australia Limited; 1993.

[23] ASTM C642-06. Standard test method for density, absorption and voids in hardened concrete. Philadelphia: ASTM International; 2006

[24] Papworth F, Green W. Concrete Penetrability. In: Taywood Engineering Limited, editor. Manual for Life Cycle Aspects of Concrete in Buildings and Structures. 2nd ed. Perth: Taylor Woodrow; 1988.

[25] Kasai Y, Nakamura N. Accelerated test method for durability of cement mortars in sea water. In: Proceedings of International Conference on Performance of Concrete in Marine Environment, St Andrews; 1980. p. 379-96.

[26] ASTM C876-09. Standard test method for half-cell potentials of uncoated reinforcing steel in concrete. Philadelphia: ASTM International; 2009.

[27] Topcu, IB, Boga, AR. 2010. Effect of ground granulate blast-furnace slag on corrosion performance of steel embedded in concrete. Mater Des. 2010;31: 3358-65.

[28] Sofi M, van Deventer JSJ, Mendis PA, Lukey GC. Engineering properties of inorganic polymer concretes (IPCs). Cem Concr Res. 2007;37:251-7.

[29] Llyod RR. Accelerated ageing of geopolymers. In: Provis JL, van Deventer JSJ, editors. Geopolymers, structure, processing, properties and industrial applications. Oxford: Woodhead Publishing Limited; 2009, p. 139-166.

[30] Rangan BV. Engineering properties of geopolymer concrete. In: Provis JL, van Deventer JSJ, editors. Geopolymers, structure, processing, properties and industrial applications. Oxford: Woodhead Publishing Limited; 2009, p. 211-226. 
[31] Popovics S, Simeonov Y, Bozhinov G, Barovsky N. Durability of reinforced concrete in sea water. In: Crane AP, editor. Corrosion of reinforcement in concrete construction; Chichester: Ellish Horwood Ltd; 1983, p. 19-37.

[32] Wallah SE. Drying shrinkage of heat-cured fly ash-based geopolymer concrete. Modern Appl Sci. 2009;3: 14-21.

[33] Masoud S, Soudki K. Evaluation of corrosion activity in FRP repaired RC beams. Cem Concr Compos. 2006;28:969-77.

[34] Yodmunee S, Yodsujai W. Study on corrosion of steel bar in fly ash based geopolymer concrete. In: Proceeding of International Conference on Pozzolan, Concrete and Geopolymer, Khon Kaen; 2006. p. 189-194.

[35] Kriven WM, Gordon M, Ervin BL, Reis H. Corrosion protection assessment of concrete reinforcing bars with a geopolymer coating. In: Proceedings of the 30th International Conference on Advanced Ceramics and Composites, Daytona Beach; 2007. Paper ID: ICACC-0008-2007.R1.

[36] FM5-522. Florida method of test for an accelerated laboratory method for corrosion testing of reinforced concrete using impressed current. Florida: Department of Transportation; 2000. 


\section{List of Figures}

Figure 1 Relationship between compressive strength and the four mix factors and their values.

Figure 2 Drying shrinkage of OPC concrete and the three optimal geopolymer concretes until 91 days after curing.

Figure 3 Weight losses during for mix T4 and the control mix during the drying process of wetting-drying cycles.

Figure 4 Change in total weight of mix T4 and control mix during wetting-drying cycles.

Figure 5 Change in half-cell potentials with respect to age for optimal and control mixes.

Figure 6 Change with time of $\mathrm{pH}$ of aqueous solution used for half-cell potential tests for optimal and control mixes.

Figure 7 Corrosion current-time relationships and $t_{\text {fail }}$ at constant voltage $(30 \mathrm{~V})$ for optimal and control mixes.

\section{List of Tables}

Table 1 Chemical compositions (wt \%) of fly ash and cement used in this study

Table 2 Factors and values tested

Table 3 Taguchi $\mathrm{OA}_{9}\left(3^{4}\right)$ orthogonal array [12]

Table 4 Factors and values used in geopolymer concrete mixture trials

Table 5 Geopolymer concrete mixtures used for Taguchi optimization

Table 6 Changes of compressive strength of trial mixes

Table 7 Compressive strength, weight loss, sorptivity and AVPV of trial mixes

Table 8 Effect of each factor on weight loss, sorptivity, and AVPV of trial mixes when the proportions of other factors were unchanged

Table 9 Mixture proportions for the three optimal mixes and the control mix

Table 10 Slump, $\mathrm{pH}$ and compressive strength $\left(f_{c}\right)$ of optimal and control concrete mixes

Table 11 Change with age of splitting strength $\left(f_{t}\right)$ and flexural strength $\left(f_{c f}\right)$ of optimal and control concrete mixes

Table 12 Change with age of modulus of elasticity (E) and Poisson's ratio of optimal and control concrete mixes at 28 and 91 days

Table 13 Water absorption, Apparent Volume of Permeable Voids (AVPV) and effective porosity of optimal and control concrete mixes at 28 and 91 days

Table 14 Sorptivity of optimal and control concrete mixes at 28 and 91 days

Table 15 Changes of compressive strength of T4 and control concrete mixes during wettingdrying cycles

Table 16 Accelerated corrosion tests at 30V for optimal and control concrete mixes 


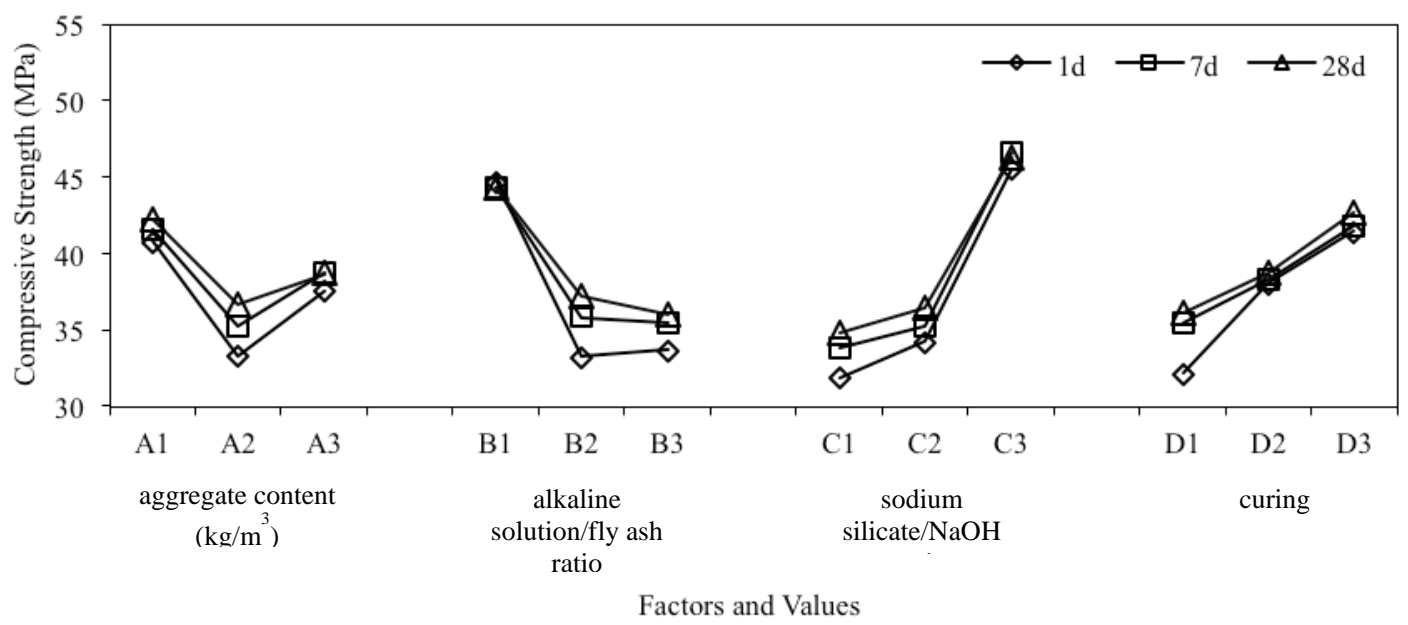

Figure 1 Relationship between compressive strength and the four mix factors and their values.

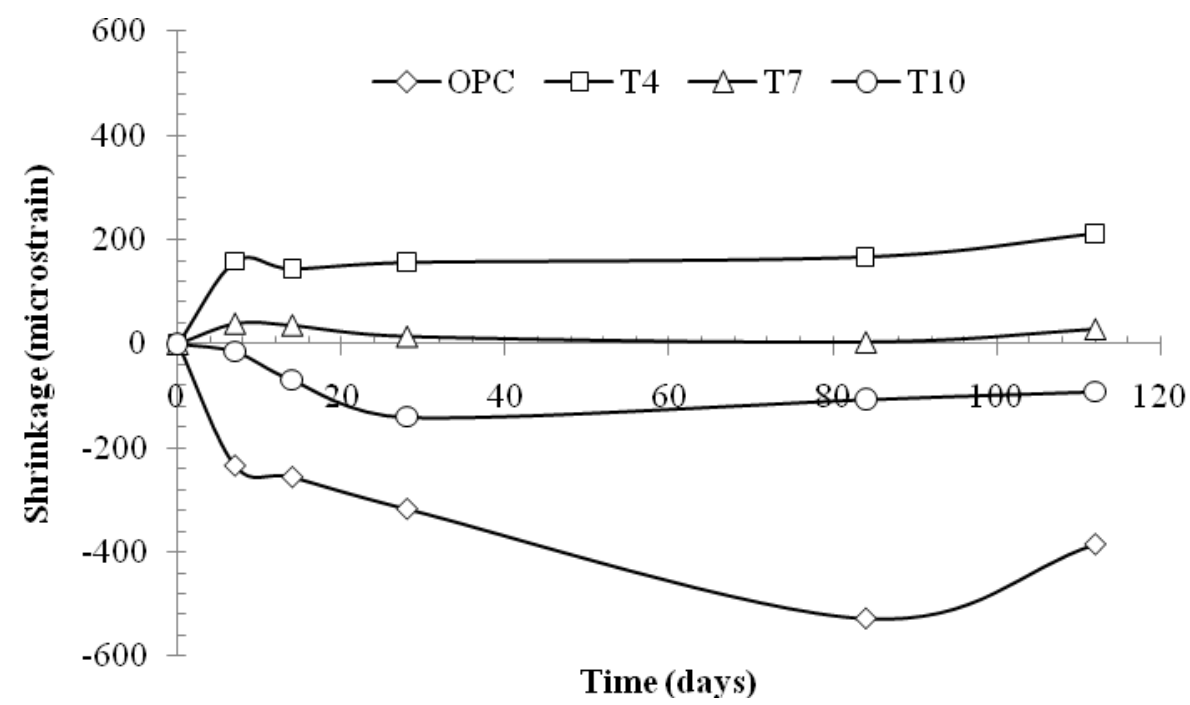

Figure 2 Drying shrinkage of OPC concrete and the three optimal geopolymer concretes until 91 days after curing. 


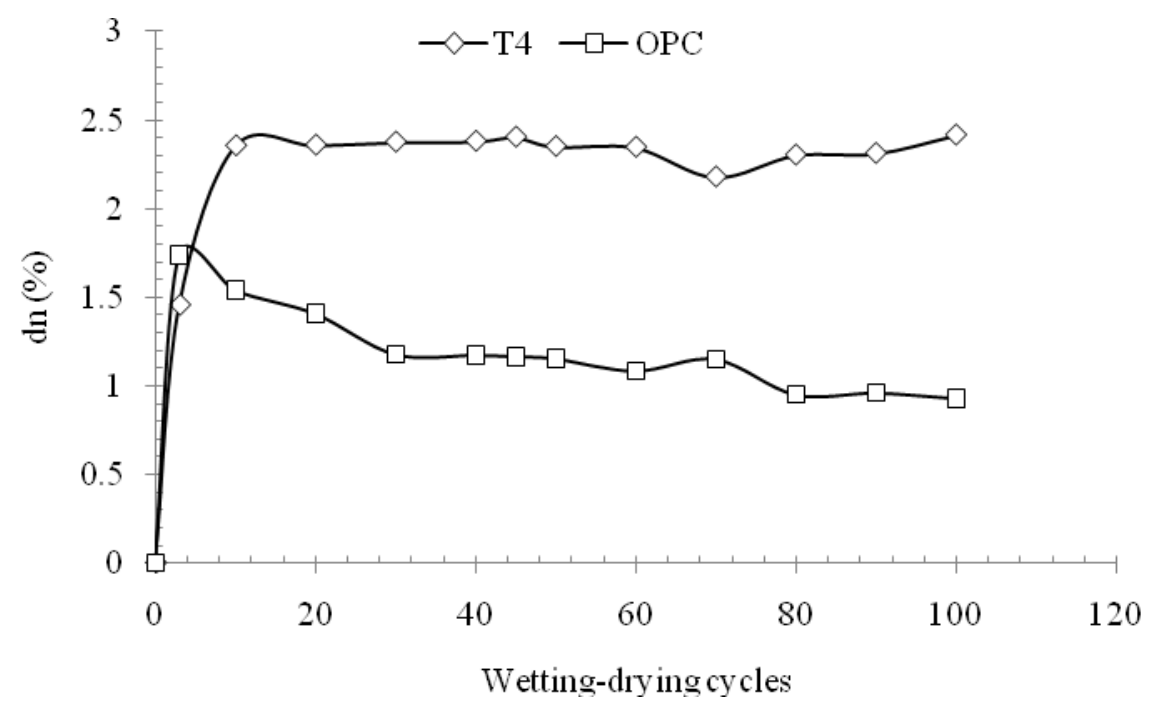

Figure 3 Weight losses during for mix T4 and the control mix during the drying process of wetting-drying cycles.

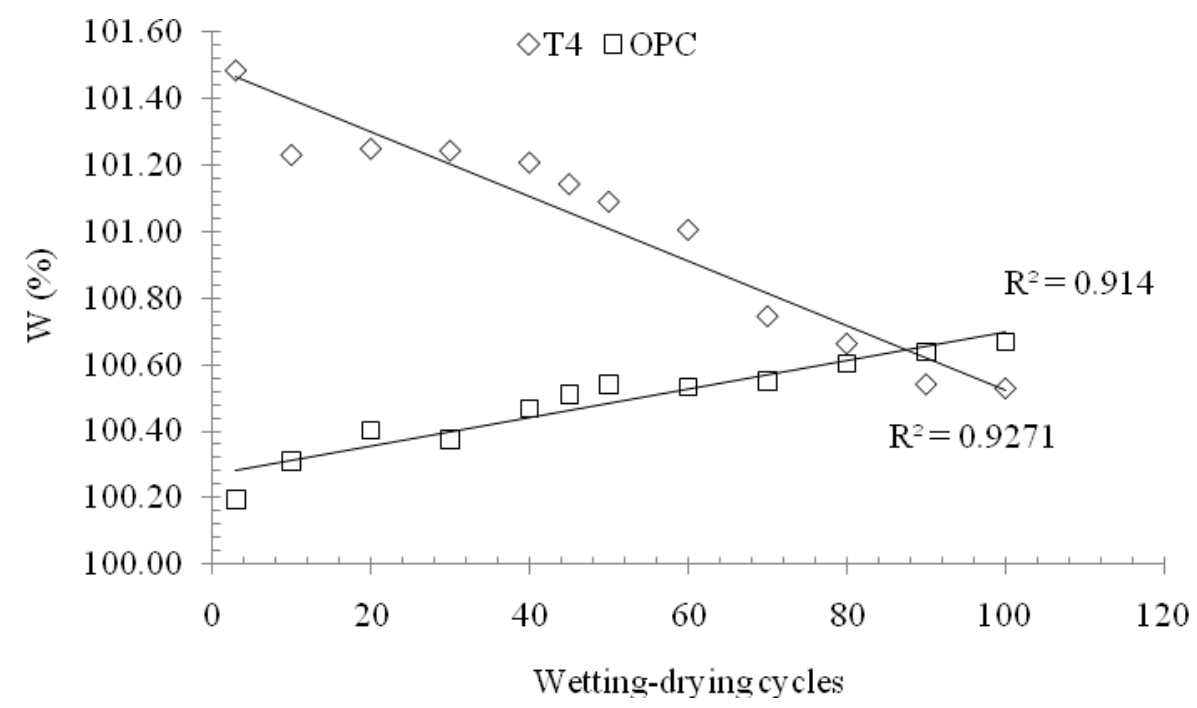

Figure 4 Change in total weight of mix T4 and control mix during wetting-drying cycles. 


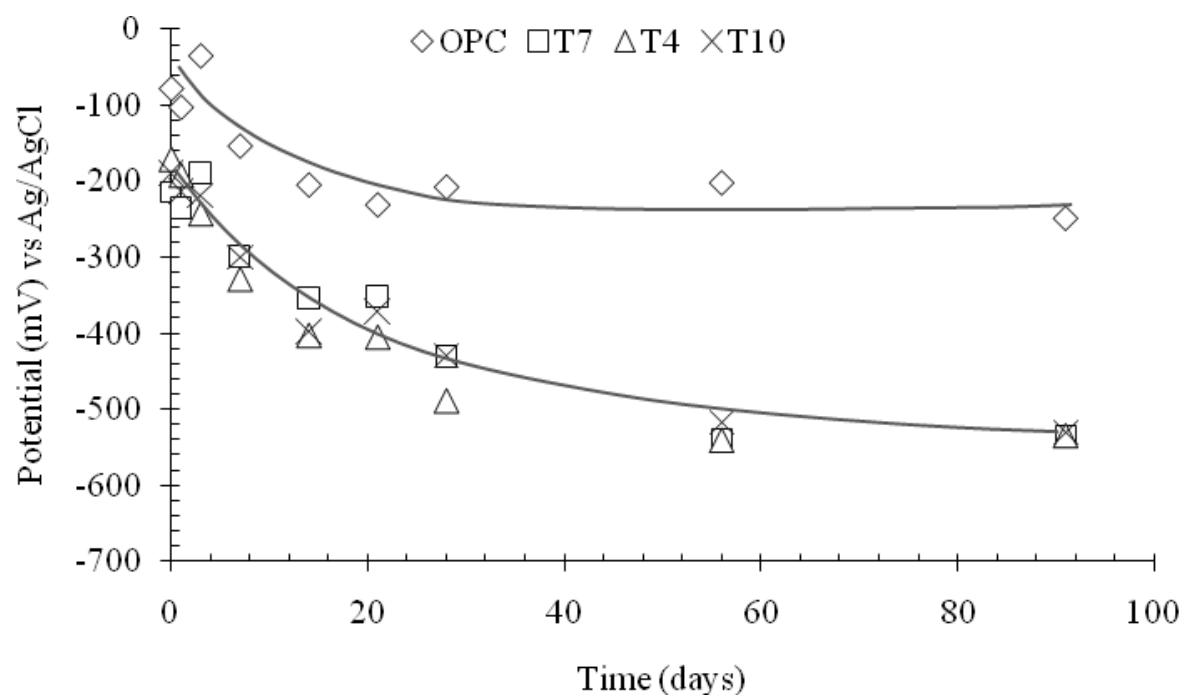

Figure 5 Change in half-cell potentials with respect to age for optimal and control mixes.

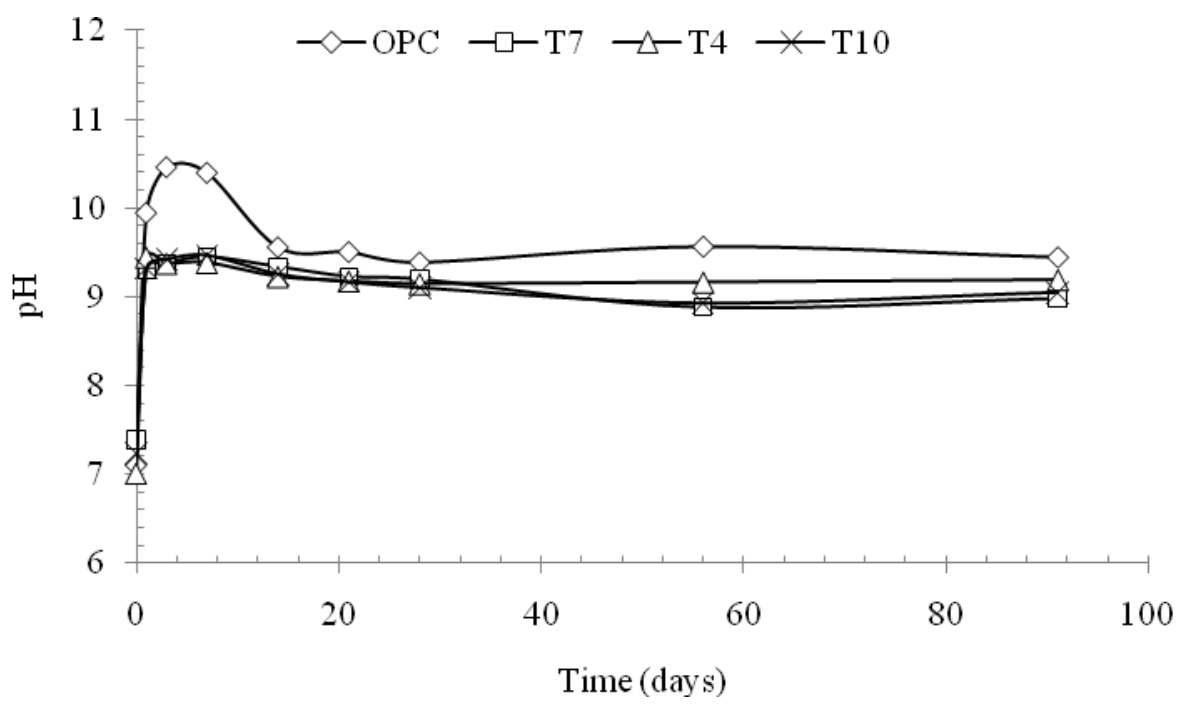

Figure 6 Change with time of $\mathrm{pH}$ of aqueous solution used for half-cell potential tests for optimal and control mixes. 


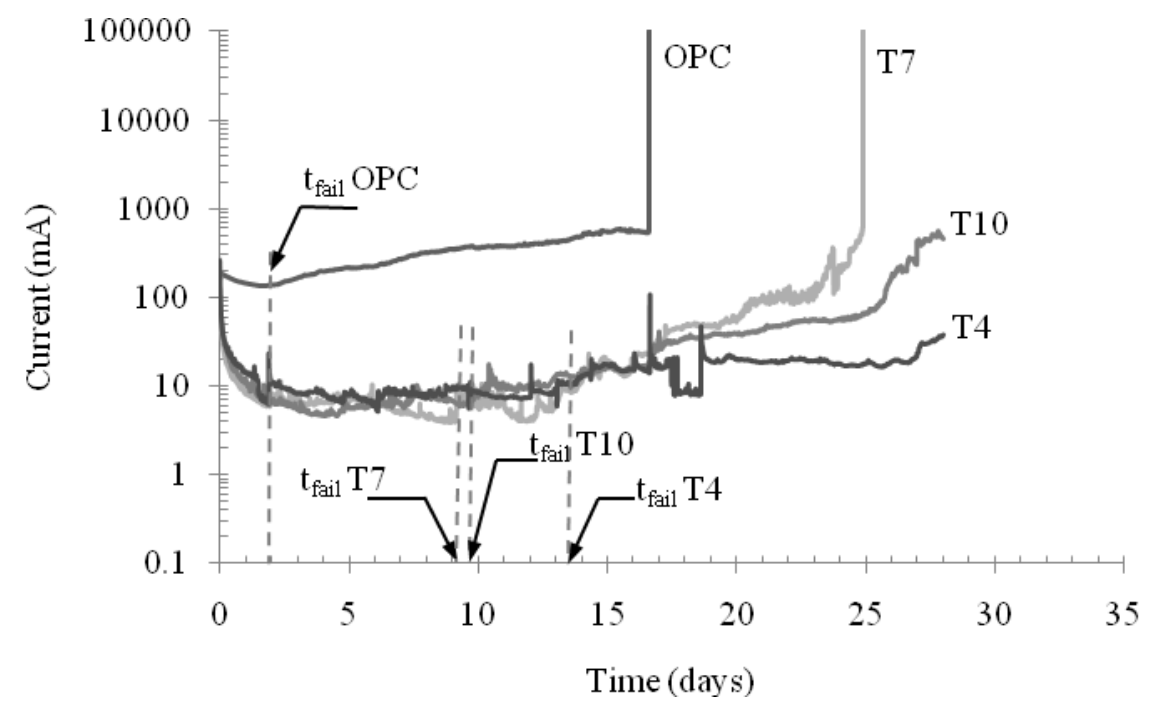

Figure 7 Corrosion current-time relationships and $\mathrm{t}_{\text {fail }}$ at constant voltage (30V) for optimal and control mixes. 
Table 1 Chemical compositions (wt \%) of fly ash and cement used in this study

\begin{tabular}{lcc}
\hline Oxides & Fly ash & Cement \\
\hline Silica $\left(\mathrm{SiO}_{2}\right)$ & 50.50 & 21.10 \\
Alumina $\left(\mathrm{Al}_{2} \mathrm{O}_{3}\right)$ & 26.57 & 4.70 \\
Calcium Oxide $(\mathrm{CaO})$ & 2.13 & 63.80 \\
Ferric oxide $\left(\mathrm{Fe}_{2} \mathrm{O}_{3}\right)$ & 13.77 & 2.80 \\
Potassium oxide $\left(\mathrm{K}_{2} \mathrm{O}\right)$ & 0.77 & - \\
Magnesium oxide $(\mathrm{MgO})$ & 1.54 & 2.00 \\
Sodium oxide $\left(\mathrm{Na}_{2} \mathrm{O}\right)$ & 0.45 & 0.50 \\
Phosporus pentoxide $\left(\mathrm{P}_{2} \mathrm{O}_{5}\right)$ & 1.00 & - \\
Sulphuric anhydride $\left(\mathrm{SO}_{3}\right)$ & 0.41 & 2.50 \\
Loss on ignition $(\mathrm{LOI})$ & 0.60 & 2.10 \\
Chloride & - & 0.01 \\
\hline
\end{tabular}

Table 2 Factors and values tested

\begin{tabular}{|c|c|c|c|}
\hline Factor & Level 1 & Level 2 & Level 3 \\
\hline A: aggregate content $\left(\mathrm{kg} / \mathrm{m}^{3}\right)$ & 1800 & 1848 & 1896 \\
\hline B: alkaline solution/fly ash ratio & 0.30 & 0.35 & 0.40 \\
\hline C: sodium silicate/NaOH ratio & 1.5 & 2 & 2.5 \\
\hline D: curing method & 24 hours $-60^{\circ} \mathrm{C}$ & 12 hours $-70^{\circ} \mathrm{C}$ & 24 hours $-75^{\mathrm{O}} \mathrm{C}$ \\
\hline
\end{tabular}

Table 3 Taguchi $\mathrm{OA}_{9}\left(3^{4}\right)$ orthogonal array [12]

\begin{tabular}{ccccc}
\hline Trial & Factor A & Factor B & Factor C & Factor D \\
\hline T1 & 1 & 1 & 1 & 1 \\
T2 & 1 & 2 & 2 & 2 \\
T3 & 1 & 3 & 3 & 3 \\
T4 & 2 & 1 & 2 & 3 \\
T5 & 2 & 2 & 3 & 1 \\
T6 & 2 & 3 & 1 & 2 \\
T7 & 3 & 1 & 3 & 2 \\
T8 & 3 & 2 & 1 & 3 \\
T9 & 3 & 3 & 2 & 1 \\
\hline
\end{tabular}


Table 4 Factors and values used in geopolymer concrete mixture trials

\begin{tabular}{ccccc}
\hline & \multicolumn{4}{c}{ Factors } \\
\cline { 2 - 5 } Trial & $\begin{array}{c}\text { Aggregate } \\
\text { content } \\
\left(\mathrm{kg} / \mathrm{m}^{3}\right)\end{array}$ & $\begin{array}{c}\text { Alkaline/fly } \\
\text { ash ratio }\end{array}$ & $\begin{array}{c}\text { Sodium } \\
\text { silicate/NaOH } \\
\text { ratio }\end{array}$ & $\begin{array}{c}\text { Curing } \\
\text { condition }\end{array}$ \\
\hline T1 & 1800 & 0.30 & 1.5 & $24 \mathrm{~h} 60^{\circ} \mathrm{C}$ \\
T2 & 1800 & 0.35 & 2.0 & $12 \mathrm{~h} 70^{\circ} \mathrm{C}$ \\
T3 & 1800 & 0.40 & 2.5 & $24 \mathrm{~h} 75^{\circ} \mathrm{C}$ \\
T4 & 1848 & 0.30 & 2.0 & $24 \mathrm{~h} 75^{\circ} \mathrm{C}$ \\
T5 & 1848 & 0.35 & 2.5 & $24 \mathrm{~h} 60^{\circ} \mathrm{C}$ \\
T6 & 1848 & 0.40 & 1.5 & $12 \mathrm{~h} 70^{\circ} \mathrm{C}$ \\
T7 & 1896 & 0.30 & 2.5 & $12 \mathrm{~h} 70^{\circ} \mathrm{C}$ \\
T8 & 1896 & 0.35 & 1.5 & $24 \mathrm{~h} 75^{\circ} \mathrm{C}$ \\
T9 & 1896 & 0.40 & 2.0 & $24 \mathrm{~h} 60^{\circ} \mathrm{C}$ \\
\hline
\end{tabular}

Table 5 Geopolymer concrete mixtures used for Taguchi optimization

\begin{tabular}{cccccccccc}
\hline Mix & $\mathrm{T} 1$ & $\mathrm{~T} 2$ & $\mathrm{~T} 3$ & $\mathrm{~T} 4$ & $\mathrm{~T} 5$ & $\mathrm{~T} 6$ & $\mathrm{~T} 7$ & $\mathrm{~T} 8$ & $\mathrm{~T} 9$ \\
\hline Fly ash $\left(\mathrm{kg} / \mathrm{m}^{3}\right)$ & 498.46 & 480.00 & 462.86 & 461.54 & 444.44 & 428.57 & 424.62 & 408.89 & 394.29 \\
Aggregates $\left(\mathrm{kg} / \mathrm{m}^{3}\right)$ & 1752 & 1752 & 1752 & 1800 & 1800 & 1800 & 1800 & 1800 & 1848 \\
NaOH $14 \mathrm{M}$ & 59.82 & 56.00 & 52.90 & 46.15 & 44.44 & 68.57 & 36.40 & 57.24 & 52.57 \\
Sodium silicate & 89.72 & 112.00 & 132.24 & 92.31 & 111.11 & 102.86 & 90.99 & 85.87 & 105.14 \\
Superplasticizer & 6.1 & 6.1 & 6.1 & 6.1 & 6.1 & 6.1 & 6.1 & 6.1 & 6.1 \\
Added water & 26.47 & 23.65 & 21.23 & 18.61 & 18.55 & 28.51 & 15.97 & 24.46 & 21.47 \\
$\mathrm{SiO}_{2} / \mathrm{Na}_{2} \mathrm{O}$ & 0.85 & 0.97 & 1.05 & 0.86 & 0.96 & 0.92 & 0.85 & 0.82 & 0.93 \\
$\mathrm{SiO}_{2} / \mathrm{Al}_{2} \mathrm{O}_{3}$ & 3.76 & 3.86 & 3.96 & 3.79 & 3.89 & 3.87 & 3.82 & 3.81 & 3.92 \\
$\mathrm{Na}_{2} \mathrm{O} / \mathrm{Al}_{2} \mathrm{O}_{3}$ & 0.42 & 0.48 & 0.54 & 0.46 & 0.51 & 0.51 & 0.49 & 0.50 & 0.56 \\
$\mathrm{H}_{2} \mathrm{O} / \mathrm{Na}_{2} \mathrm{O}$ (design) & 12.50 & 12.50 & 12.50 & 12.50 & 12.50 & 12.50 & 12.50 & 12.50 & 12.50 \\
$\mathrm{H}_{2} \mathrm{O} / \mathrm{Na}_{2} \mathrm{O}$ (actual) & 12.50 & 12.36 & 12.28 & 11.71 & 11.76 & 13.13 & 11.18 & 12.45 & 12.26 \\
\hline
\end{tabular}

Table 6 Changes of compressive strength of trial mixes

\begin{tabular}{ccccc}
\hline \multirow{2}{*}{$\begin{array}{c}\text { Trial } \\
\text { Mix }\end{array}$} & \multirow{2}{*}{ Combination } & \multicolumn{3}{c}{ Compressive strength (MPa) } \\
\cline { 3 - 5 } & & 1 day & 7 days & 28 days \\
\hline T1 & A1B1C1D1 & 37.81 & 39.52 & 39.93 \\
T2 & A1B2C2D2 & 34.56 & 35.31 & 37.09 \\
T3 & A1B3C3D3 & 49.67 & 49.89 & 49.64 \\
T4 & A2B1C2D3 & 41.92 & 40.93 & 42.51 \\
T5 & A2B2C3D1 & 32.45 & 37.55 & 38.69 \\
T6 & A2B3C1D2 & 25.17 & 27.16 & 28.64 \\
T7 & A3B1C3D2 & 54.10 & 52.29 & 54.89 \\
T8 & A3B2C1D3 & 32.40 & 34.53 & 35.73 \\
T9 & A3B3C2D1 & 25.86 & 29.29 & 29.71 \\
\hline
\end{tabular}


Table 7 Compressive strength, weight loss, sorptivity and AVPV of trial mixes

\begin{tabular}{|c|c|c|c|c|c|c|c|}
\hline $\begin{array}{l}\text { Trial } \\
\text { Mix }\end{array}$ & Combination & $\begin{array}{l}\text { Compressive } \\
\text { strength } \\
\text { after } \\
\text { wetting- } \\
\text { drying } \\
\text { (MPa) } \\
\end{array}$ & $\begin{array}{l}\text { Change in } \\
\text { compressive } \\
\text { strength (\%) }\end{array}$ & $\begin{array}{c}\text { Weight } \\
\text { loss } \\
\text { during } \\
\text { drying } \\
\text { process } \\
(\%) \\
\end{array}$ & $\begin{array}{c}\text { Total } \\
\text { weight } \\
\text { change } \\
(\%)\end{array}$ & $\begin{array}{l}\text { Sorptivity } \\
\left(\mathrm{mm} / \mathrm{min}^{0.5}\right)\end{array}$ & $\begin{array}{c}\text { AVPV } \\
(\%)\end{array}$ \\
\hline $\mathrm{T} 1$ & A1B1C1D1 & 52.62 & 33.15 & 2.65 & 101.51 & 0.1324 & 8.86 \\
\hline $\mathrm{T} 2$ & A1B2C2D2 & 50.44 & 42.85 & 2.78 & 101.79 & 0.1344 & 9.54 \\
\hline T3 & A1B3C3D3 & 59.48 & 19.22 & 2.80 & 101.14 & 0.1174 & 9.87 \\
\hline $\mathrm{T} 4$ & A2B1C2D3 & 55.48 & 35.55 & 2.55 & 100.45 & 0.1034 & 8.33 \\
\hline T5 & A2B2C3D1 & 47.87 & 27.48 & 2.59 & 101.54 & 0.1280 & 9.09 \\
\hline T6 & A2B3C1D2 & 38.20 & 40.65 & 3.14 & 101.57 & 0.1806 & 9.95 \\
\hline T7 & A3B1C3D2 & 69.81 & 33.51 & 1.97 & 101.04 & 0.0805 & 7.42 \\
\hline T8 & A3B2C1D3 & 42.11 & 21.95 & 2.76 & 100.69 & 0.1538 & 8.96 \\
\hline T9 & A3B3C2D1 & 37.92 & 29.46 & 2.92 & 101.73 & 0.1561 & 10.60 \\
\hline
\end{tabular}

Table 8 Effect of each factor on weight loss, sorptivity, and AVPV of trial mixes when the proportions of other factors were unchanged

\begin{tabular}{cccc}
\hline Values & Mass Loss $(\%)$ & $\begin{array}{c}\text { Sorptivity } \\
\left(\mathrm{mm} / \mathrm{min}^{0.5}\right)\end{array}$ & AVPV (\%) \\
\hline A1 & 2.74 & 0.1281 & 9.423 \\
A2 & 2.76 & 0.1373 & 9.123 \\
A3 & 2.55 & 0.1301 & 8.993 \\
B1 & 2.39 & 0.1054 & 8.203 \\
B2 & 2.71 & 0.1387 & 9.197 \\
B3 & 2.95 & 0.1514 & 10.140 \\
C1 & 2.85 & 0.1556 & 9.257 \\
C2 & 2.75 & 0.1313 & 9.490 \\
C3 & 2.45 & 0.1086 & 8.793 \\
D1 & 2.72 & 0.1388 & 9.517 \\
D2 & 2.63 & 0.1318 & 8.970 \\
D3 & 2.70 & 0.1249 & 9.053 \\
\hline
\end{tabular}

Table 9 Mixture proportions for the three optimal mixes and the control mix

\begin{tabular}{lccccccc}
\hline & \multicolumn{7}{c}{ Unit weight $\left(\mathrm{kg} / \mathrm{m}^{3}\right)$} \\
\cline { 2 - 8 } \multicolumn{1}{c}{ Mixtures } & Fly ash & \multirow{2}{*}{ Cement } & $\begin{array}{c}\text { Total } \\
\text { aggregate }\end{array}$ & $\begin{array}{c}\mathrm{NaOH} \\
14 \mathrm{M}\end{array}$ & $\mathrm{Na}_{2} \mathrm{SiO}_{3}$ & $\mathrm{SP}$ & \multirow{2}{*}{ Water } \\
\hline OPC (control) & - & 422.3 & 1788.3 & - & - & - & 190 \\
T7 (A3B1C3D2) & 424.6 & - & 1848.0 & 36.4 & 90.9 & 6.4 & 17.9 \\
T4 (A2B1C2D3) & 461.5 & - & 1800.0 & 46.2 & 92.3 & 6.9 & 18.6 \\
T10 (A1B1C3D3) & 498.5 & - & 1752.0 & 42.7 & 106.7 & 7.5 & 18.8 \\
\hline
\end{tabular}


Table 10 Slump, $\mathrm{pH}$ and compressive strength $\left(f_{c}\right)$ of optimal and control concrete mixes

\begin{tabular}{lcccccccc}
\hline \multirow{2}{*}{ Mixtures } & Slump & Fresh & \multicolumn{2}{c}{7 days } & \multicolumn{2}{c}{ 28 days } & \multicolumn{2}{c}{91 days } \\
\cline { 4 - 8 } & $(\mathrm{mm})$ & concrete & $f_{c}(\mathrm{MPa})$ & $\mathrm{SD}$ & $f_{c}(\mathrm{MPa})$ & $\mathrm{SD}$ & $f_{c}(\mathrm{MPa})$ & $\mathrm{SD}$ \\
& & $\mathrm{pH}$ & & & & & & \\
\hline OPC (control) & 90 & 12.00 & 51.23 & 4.94 & 56.22 & 1.63 & 65.15 & 4.30 \\
T7 & 180 & 12.12 & 54.04 & 1.83 & 56.49 & 1.28 & 56.51 & 0.78 \\
T4 & 240 & 12.30 & 55.27 & 1.42 & 56.24 & 4.45 & 58.85 & 3.48 \\
T10 & 250 & 12.27 & 59.08 & 1.92 & 60.20 & 5.40 & 63.29 & 5.62 \\
\hline
\end{tabular}

Table 11 Change with age of splitting strength $\left(f_{t}\right)$ and flexural strength $\left(f_{c f}\right)$ of optimal and control concrete mixes

\begin{tabular}{lcccccccc}
\hline \multirow{2}{*}{ Mixtures } & \multicolumn{2}{c}{ 28 days } & \multicolumn{2}{c}{ 91 days } & \multicolumn{2}{c}{ 28 days } & \multicolumn{2}{c}{ 91 days } \\
\cline { 2 - 9 } & \multicolumn{2}{c}{ Splitting strength } & \multicolumn{2}{c}{ Splitting strength } & \multicolumn{2}{c}{ Flexural strength } & \multicolumn{2}{c}{ Flexural strength } \\
\cline { 2 - 8 } & $f_{t}(\mathrm{MPa})$ & SD & $f_{t}(\mathrm{MPa})$ & SD & $f_{c f}(\mathrm{MPa})$ & SD & $f_{c f}(\mathrm{MPa})$ & SD \\
\hline OPC (control) & 3.97 & 0.49 & 4.25 & 0.13 & 7.33 & 0.96 & 7.02 & 0.74 \\
T7 & 4.13 & 0.07 & 4.18 & 0.34 & 7.39 & 0.63 & 9.21 & 0.43 \\
T4 & 3.96 & 0.16 & 4.10 & 0.19 & 8.99 & 0.30 & 9.36 & 0.44 \\
T10 & 4.29 & 0.32 & 4.79 & 0.33 & 8.38 & 0.58 & 9.85 & 0.53 \\
\hline
\end{tabular}

Table 12 Change with age of modulus of elasticity (E) and Poisson's ratio of optimal and control concrete mixes at 28 and 91 days

\begin{tabular}{lcccccccc}
\hline \multirow{2}{*}{ Mixtures } & \multicolumn{2}{c}{$\begin{array}{c}\text { 28 days } \\
\text { Mod. of elasticity }\end{array}$} & \multicolumn{2}{c}{ 91 days } & \multicolumn{2}{c}{28 days } & \multicolumn{2}{c}{91 days } \\
& Mof elasticity & \multicolumn{2}{c}{ Poisson's Ratio } & \multicolumn{2}{c}{ Poisson’s Ratio } \\
\cline { 2 - 9 } & $E(\mathrm{GPa})$ & SD & $E(\mathrm{GPa})$ & SD & $\mu$ & SD & $\mu$ & SD \\
\hline OPC (control) & 34.16 & 0.54 & 37.64 & 2.34 & 0.14 & 0.02 & 0.15 & 0.05 \\
T7 & 25.33 & 2.27 & 27.18 & 3.98 & 0.15 & 0.01 & 0.17 & 0.04 \\
T4 & 26.95 & 0.32 & 28.03 & 1.16 & 0.13 & 0.02 & 0.15 & 0.02 \\
T10 & 29.05 & 1.74 & 26.80 & 0.22 & 0.15 & 0.03 & 0.15 & 0.01 \\
\hline
\end{tabular}

Table 13 Water absorption, Apparent Volume of Permeable Voids (AVPV) and effective porosity of optimal and control concrete mixes at 28 and 91 days

\begin{tabular}{|c|c|c|c|c|c|c|c|c|c|c|}
\hline \multirow{3}{*}{ Mixtures } & \multirow{2}{*}{\multicolumn{2}{|c|}{$\begin{array}{c}28 \text { days } \\
\begin{array}{c}\text { Water } \\
\text { absorption }\end{array}\end{array}$}} & \multirow{2}{*}{\multicolumn{2}{|c|}{$\begin{array}{c}\text { 91 days } \\
\begin{array}{c}\text { Water } \\
\text { absorption }\end{array}\end{array}$}} & \multirow{2}{*}{\multicolumn{2}{|c|}{$\begin{array}{l}28 \text { days } \\
\text { AVPV }\end{array}$}} & \multirow{2}{*}{\multicolumn{2}{|c|}{$\begin{array}{l}91 \text { days } \\
\text { AVPV }\end{array}$}} & 28 days & 91 days \\
\hline & & & & & & & & & \multirow{2}{*}{\multicolumn{2}{|c|}{$\begin{array}{l}\text { Effective Porosity } \\
\text { (\%) }\end{array}$}} \\
\hline & $(\%)$ & SD & $(\%)$ & SD & $(\%)$ & SD & $(\%)$ & SD & & \\
\hline OPC (control) & 5.09 & 0.07 & 5.14 & 0.20 & 11.72 & 0.09 & 11.95 & 0.44 & 11.73 & 11.56 \\
\hline T7 & 3.79 & 0.19 & 3.45 & 0.07 & 9.43 & 0.22 & 8.47 & 0.26 & 8.71 & 8.31 \\
\hline $\mathrm{T} 4$ & 3.45 & 0.18 & 3.77 & 0.12 & 8.15 & 0.36 & 9.21 & 0.37 & 8.58 & 8.02 \\
\hline $\mathrm{T} 10$ & 4.33 & 0.19 & 3.73 & 0.17 & 10.89 & 0.71 & 9.24 & 0.20 & 9.76 & 8.42 \\
\hline
\end{tabular}


Table 14 Sorptivity of optimal and control concrete mixes at 28 and 91 days

\begin{tabular}{lcccc}
\hline \multirow{2}{*}{ Mixtures } & \multicolumn{2}{c}{ 28 days } & \multicolumn{2}{c}{91 days } \\
\cline { 2 - 5 } & \multicolumn{2}{c}{ Sorptivity } & \multicolumn{2}{c}{ Sorptivity } \\
\cline { 2 - 5 } & $S\left(\mathrm{~mm} / \mathrm{min}^{0.5}\right)$ & $\mathrm{R}^{2}$ & $S\left(\mathrm{~mm} / \mathrm{min}^{0.5}\right)$ & $\mathrm{R}^{2}$ \\
\hline OPC (control) & 0.1888 & 0.9968 & 0.2027 & 0.9892 \\
T7 & 0.1060 & 0.9846 & 0.1624 & 0.9921 \\
T4 & 0.0813 & 0.9954 & 0.1029 & 0.9961 \\
T10 & 0.1354 & 0.9963 & 0.1264 & 0.9974 \\
\hline
\end{tabular}

Table 15 Changes of compressive strength of T4 and control concrete mixes during wettingdrying cycles

\begin{tabular}{lcccccc}
\hline $\begin{array}{l}\text { Wetting- } \\
\text { drying } \\
\text { cycles }\end{array}$ & $\begin{array}{c}\text { Compressive } \\
\text { strength } \\
(\mathrm{MPa})\end{array}$ & SD & $\begin{array}{c}\text { Change in } \\
\text { compressive } \\
\text { strength (\%) }\end{array}$ & $\begin{array}{c}\text { Compressive } \\
\text { strength } \\
(\mathrm{MPa})\end{array}$ & $\begin{array}{c}\text { SD } \\
\text { Change in } \\
\text { compressive } \\
\text { strength (\%) }\end{array}$ \\
\hline 0 & 54.19 & 2.89 & 0 & 51.23 & 4.94 & 0 \\
14 & 68.95 & 5.51 & 21.41 & 59.78 & 1.72 & 14.31 \\
45 & 72.03 & 4.76 & 24.77 & 57.09 & 1.83 & 10.26 \\
100 & 62.26 & 3.43 & 12.96 & 56.55 & 5.25 & 9.40 \\
\hline
\end{tabular}

Table 16 Accelerated corrosion tests at 30V for optimal and control concrete mixes

\begin{tabular}{lcccc}
\hline Mixtures & $\begin{array}{c}\text { Initial current } \\
(\mathrm{mA})\end{array}$ & $\begin{array}{c}\text { Final } \\
\text { current } \\
(\mathrm{mA})\end{array}$ & $\begin{array}{c}\text { Time to } \\
\text { failure } \\
\text { (days) }\end{array}$ & $\begin{array}{c}\text { Electrical } \\
\text { resistance } \\
\text { (k-ohm) }\end{array}$ \\
\hline OPC (control) & 163.64 & 99999.99 & 2.27 & 0.14 \\
T7 & 218.04 & 99999.99 & 8.77 & 4.25 \\
T4 & 259.88 & 38.14 & 12.94 & 9.42 \\
T10 & 268.02 & 66.33 & 9.22 & 6.22 \\
\hline
\end{tabular}

